\title{
Mystical Délirants Prone to Criminality
}

\section{Sinan Çaya*}

Department of Sociology, Faculty of Sciences and Letters, Istinye University, Istanbul, Turkey

\begin{abstract}
Some forms of paraphrenia involve hallucinations of a mystical nature, whereby an inner voice would issue irresistible commands, which the patient would invariably execute. In certain given situations, such commands may be linked to really criminal acts including murder of specifically depicted individuals. Literature of Behavioral Sciences registers a number of such cases, which are all interesting to study from a scientific viewpoint.
\end{abstract}

Keywords: Mystical; Delusion; Crime

\section{Introduction}

Roughly put, neurosis is a reaction of nerves and can be cured fairly easily. It is of affective nature. The patient protects his personality as a whole and is in contact with reality. Psychosomatic organ disorders (ulcer, asthma, constant headaches, some hypertension cases) are explained through the same mechanism. Psychosis, on the other hand, is what in vernacular language is known as being "crazy" [1].

Clinical psychoses with hallucinations involve various délires (delusions). In other words, the patient loses contact with reality and can't preserve his entire personality (as in schizophrenia or paranoia) [2]. We encounter a wide spectrum in classification [1] of paraphrenias, among which mystical delirious cases also take place. Many such cases are sheer mental disorders like other hallucinatory cases, in the sense that the patient is not considered as a dangerous individual towards others. Philosophically speaking he/she is always dangerous towards himself/herself, indeed. However, some of the cases are associated with serious felonies.

Mysticism deliriums involve pathological levels of being pious. Seeing Messiah (theopathy), spiritism (occultism deliriums), thinking he is Messiah (paranoia Messianic), cutting himself (especially in genitals, as it was voluntarily practiced in some monasteries in former times by some monks) in order to escape the devil's suggestion and influence (auto-mutilation) [2]. Let us note that; a deeply devout and ascetic Moslem-mystic with sound mind, is not to be confused with such a patient. Nevertheless, such a patient's Islamic version exists and is known as meczup [3] or mecnun (Figure 1) in Turkish culture [1].

\section{Murder with, pure and even "celestial" intentions}

Dr. Belli at Çukurova University's Legal Medicine Chair (1981) narrated a murder case dating back to thirty years, already at the time: A middle-aged shepherd kills a little girl who used to carry him food and drink regularly from the nearby village \{Shepherds do need a chain of food supply extending to the wilderness where they lead the herds of sheep. A story by the classical French story-teller A Daudet [4,5], deals with that theme. The delicate adolescent daughter of the boss brings food to a young shepherd. The rain and the flood hinder her return. She stays overnight, conversing with the shepherd and falling asleep like the most precious lamb of the stockyard. The young man feels honored and watches over her until the sunrise.

He does not even attempt to hide the "crime". Cross-examination soon illuminates surprising findings. The man does not want this nice little girl to grow up and get involved in sensuous vice, thereby becoming a wicked woman. He prefers to send this innocent soul to the Paradise with a guaranteed shortcut. The inquisitors ask:

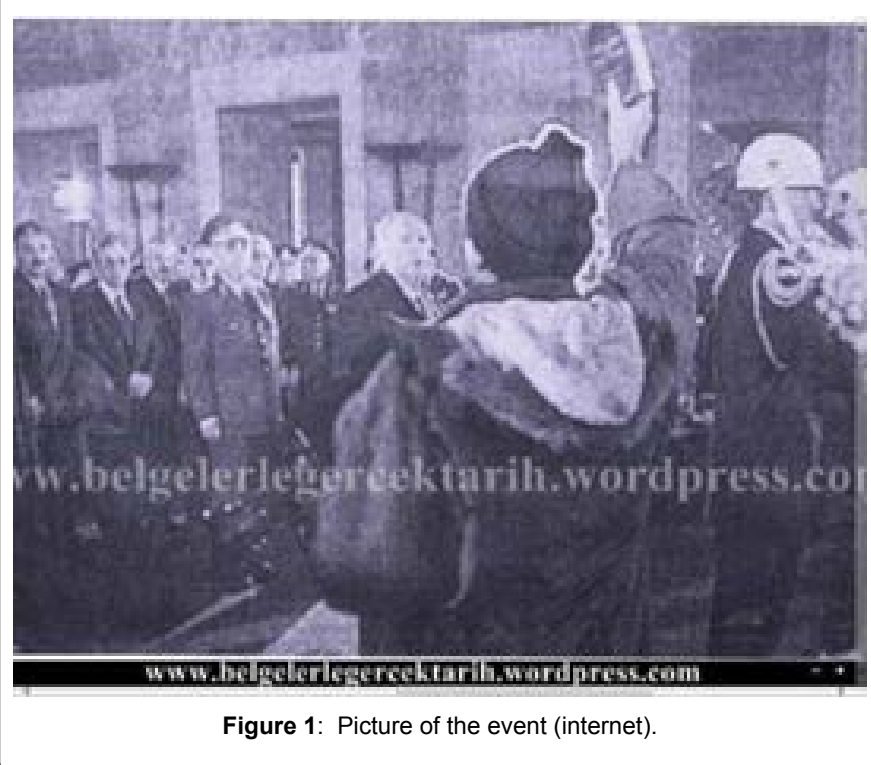

-But you became a killer, a most wicked personality.

- No, this is a special situation. It is I who caused her eternal peace and bliss. Therefore, in the after-world she will intercede for me. Just for her sake, God shall forgive all my past wrongs and sins and accept me into the Paradise, as well.

Belli commented that this was a typical schizophrenia way of reasoning village the layman usually assumes that a lunatic is deprived of rational thinking. In fact, experts know that they possess a very functional logic, which merely works differently or morbidly.

\section{An Italian movie deals with the theme}

In an Italian movie (Figure 2) directed by Lucio Fulci in 1972 deals with a similar theme, namely the Christian version of the deranged good-willed idea.

*Corresponding author: Sinan Çaya, Department of Sociology, Faculty of Sciences and Letters, Istinye University, Istanbul, Turkey, Tel: +02123117643; E-mail:sinan.caya@gmail.com

Received: May 08, 2017; Accepted: June 02, 2017; Published: June 09, 2017

Citation: Çaya S (2017) Mystical Délirants Prone to Criminality. J Psychiatry 20 414. doi:10.4172/2378-5756.1000414

Copyright: @ 2017 Çaya S. This is an open-access article distributed under the terms of the Creative Commons Attribution License, which permits unrestricted use, distribution, and reproduction in any medium, provided the original author and source are credited 


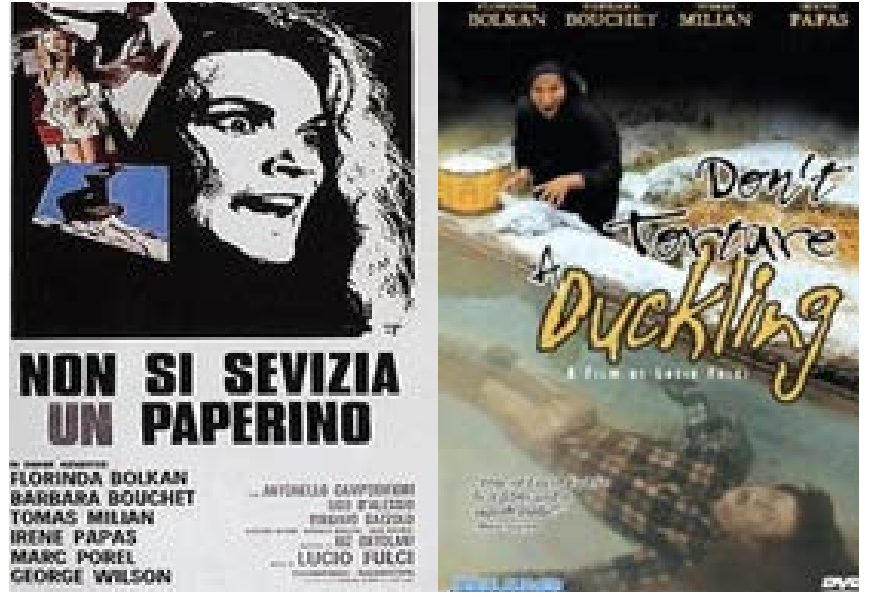

Figure 2: The posters of the movie in Italian and in English (internet)

A reporter (Martelli) and a promiscuous young woman Patrizia (Barbara Bouchet) (who seems misplaced there but feels obliged to hide herself from urban regions for a time, following a drug scandal) try to solve a series of child killings in a remote superstitious southern Italian town.

Martelli befriends Patrizia whom he recognizes from newspapers. Patrizia is considered a whore by the rest of the isolated villagers due to her decollete attire. Meanwhile, in the hills surrounding the village, a reclusive Gypsy witch named La Magiara (Florinda Bolkan) [4,5], is conducting black magic ceremoniesby piercing needles into clay dolls. Martelli also meets with the young village priest, Don Alberto Avallone (Marc Poreli) and his strangely reserved mother Aurelia (Irene Papas).

Don Alberto runs a boys group at the church (which the murder victims came from) and he also encourages the boys to play soccer on the church grounds to keep them out of trouble. Don Alberto is known and respected by everyone in the village. But Aurelia is a, sulky mysterious woman. A villager confides in Martelli that, "she is only tolerated because she is the priest's mother".

Don Alberto is the killer, he strangled the boys, not for their sins, but to prevent them from committing sin when they grow up, as well as to save them from the "horrors of sexuality", thus sending them to Heaven with clean souls.

Don Alberto tries to throw his little sister, a witness to the crimes, off a cliff. Martelli arrives in the nick of time, and after a fistfight between Martelli and Don Alberto, the insane priest loses his footing and falls off the cliff.

\section{A true memory by medical doctor Ersevim}

Ersevim [6] mentions a true psychiatric patient in a documentarylike short story format: A deeply-pious, robust and young provincial man in the Thracian region of the country takes a long train journey to the big city, Istanbul (Figure 3). Among several sky-scraping minarets, he picks out one mosque that has six of them (the famous Blue Mosque, Sultan Ahmet). As Eshref arrives, Chief Imam (Islamic for-prayer) greets him respectfully.

Eventually, Eshref gets the impression that the Chief Imam himself does not seem to be performing the Five Commandments of the great Muslim religion. He reasons that this man cannot represent a highstatus man of clergy. He commits himself to do what he is ordained to do.

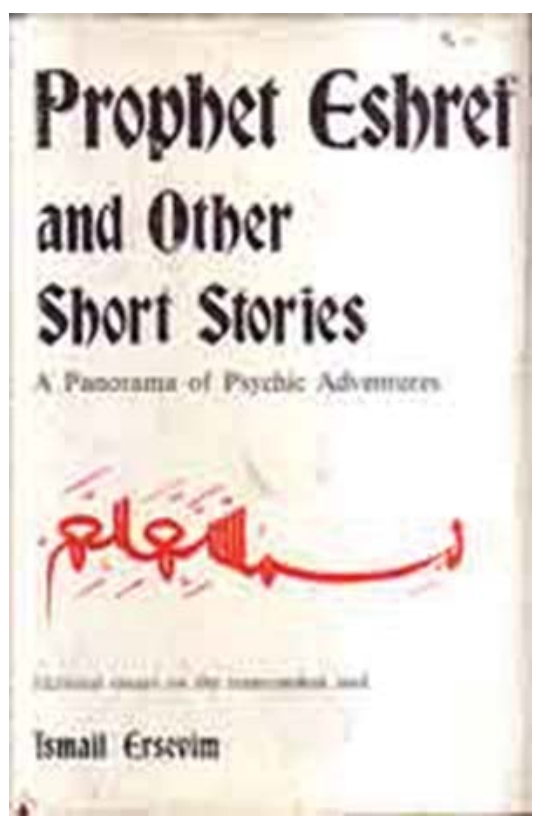

Figure 3: Cover of the book by Ersevim.

One day the old man feels Eshref's strong, steel-like fingers circle around his frail, turkey-skinned neck. "I am the messenger of Koran, I am the prophet Eshref, the last to come down to the earth" he sighs with tremendous relief in his heart, a flush of glory in his eyes. It takes just a few hours before the gendarmeries get him with no resistance and convey him first to a very special court session and later to the asylum. Over time, asylums became mental hospital, while lunatics became mentally deranged people. The euphemism is indeed getting to represent the truth more and more.

In a later episode of the story we encounter Eshref as a regular inmate, a soft-spoken and always-smiling elderly man who also sells cigarettes, candies and matches to the visitors. In fact, he is a goodwill ambassador between the administration and the patients. In his poems, he addresses to the superintendent and implores for more favors:

Dear Doctor Usman [5] (Figure 4)

Please see this suffering soul, this poor man!

I love mankind, everyone, and Nature, you, kind doctor!

Certain psychopaths abuse him by leaving a note under his pillow, from the mouth of God-Almighty Himself (jamais! never!). The note confirms his being the very last messenger and orders donations like six packs of cigarettes to $K$, two pairs of socks to $M$, six bottles of soda to P Needless to say, those wishes are carried out gracefully. Eshref grins as he murmurs that those men will be his sponsors in heaven. Eshref is also in perpetual wait of the sacred sword of Prophecy.

Some students or assistants would sometimes question Prophet Eshref or carry on a delightful conversation with him. Patients claiming to be Napoleon or General De Gaulle would never do that. On a full moon night in 1953, young MD Ersevim, the physician on duty, witnesses the sudden and peaceful death of Eshref at the bottom floor of the sixty-bed ward and closes his eyelids.

\section{Impressions from French literary work}

A novel by a contemporary French author [7] (Figure 5) deals 


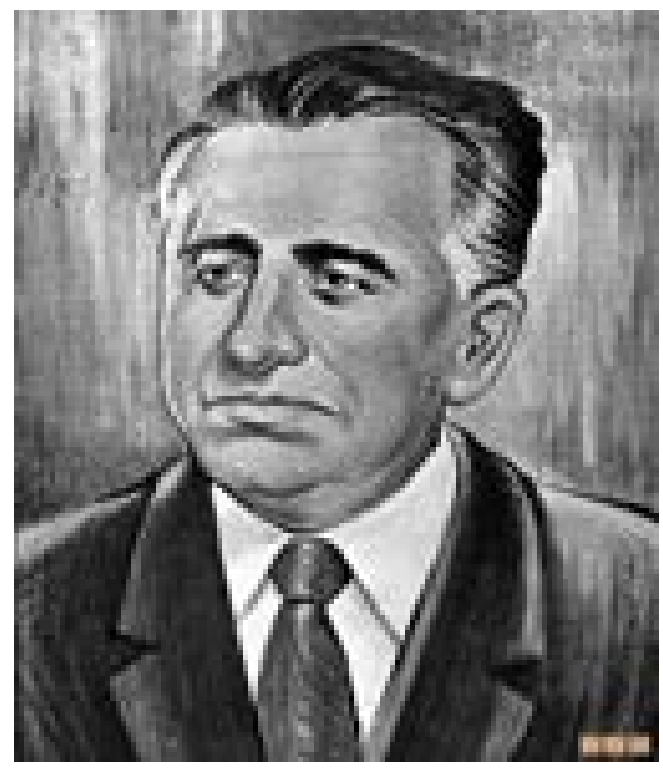

Figure 4: M.D. Mazhar Osman Usman.

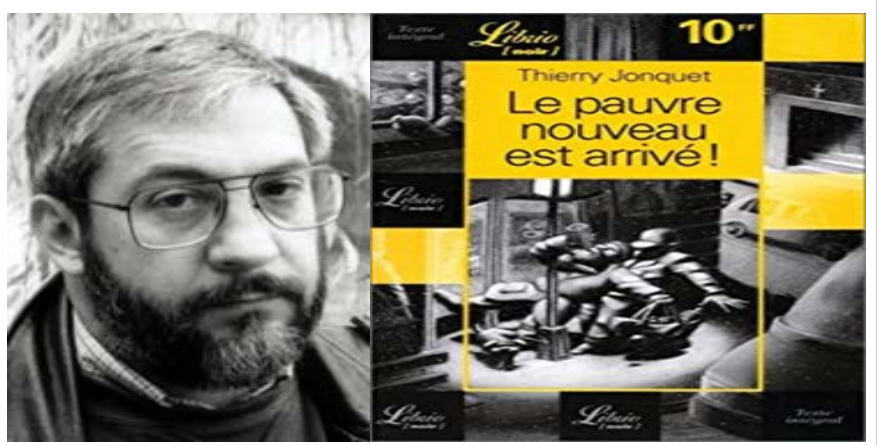

Figure 5: French author Thierry Jonquet (1954-2009) and his book (internet).

with the same theme of psychiatry, if only as one of the rich number of subthemes [6] taken in the book:

Étienne, the marquis, (more specifically Étienne Chabot de Vaudricourt de la Muzardière-Huzart) is the last offspring of an aristocratic but unlucky (or even condemned: Bankruptcies, betrayals, executions) lineage. Though officially abolished in France since the days of the Revolution, the nobility titles still survive within the French society, if only in a purely nominal manner.

He is in charge of the marketing branch of a giant company which manufactures artificial flowers. Sales fall visa-versa the Japanese competition. A restructuring decision (concentrating efforts in production of religious articles [7], instead) hits him hard. He loses his job. His wife (Henrietta) proves to be very unconcerned. On one occasion, she screams that he is a complete failure (un raté) like all his ancestors and lets him down (She is having an illegitimate affair, anyhow and she will find herself in the arms of Marcel).

The noble man with no financial support soon ends up in the streets, among the homeless people of Paris, eating soup from the travelling church-kitchens and sleeping in subway stations. His clothing gets dirty and shabby in no time, completing his new miserable image, for good.
Then, as if all this suffering is not enough, a looming terror emerges: A mysterious killer starts choosing vagrants as his victims, one by one. The police force feels a huge social pressure. Agents disguised as tramps roam the city, but in vain.

Étienne, the fallen marquis, finally decides to commit suicide one evening in the court of a small church. At this very moment, he hears a conversation between a male voice and a female voice.

He distinguishes Jules, the Ecclesiastical Dignitary in charge of the food distribution, talking to a nun, whose face is veiled and whose head is covered with a cornet. She is busy, telling her rosary (Catholic chaplet).

-Please, Dear Sister, take my confession, will you?

-But such a practice is forbidden.

-Yes, but I can't go to a priest! It is you who will hear me and come up with a decision regarding my being in error or not!

The nun sighs and agrees.

-O.K. just because you are my brother!

-Do you still remember our childhood games, Ernestine? You used to hide my missal (liturgical book).

— And you used to hide my candles.

The marquis was swearing internally fort his intervention which would delay his suicide. But then his interest did awake. The nun is horrified. She escapes while promising to keep silent about this matter for ever. So many things got mentioned all of a sudden: The Street people. The small trucks offered to the church for carrying soup. Since God was converted into communism [8], Saint Francis (Figure 6) [9], felt himself forced to take the reins into his own holy hands, in order to reconstruct the just order. The Saint was promising a redemption, an important part of which consisted in sacrificing some tramps.

Now the marquis is more enthusiastic to survive than ever. His share of the opportunity would be regaining a job and a social status. He denounces the actor of the infamous crimes to the police. But a bargain with the church ensues. The mystical criminal is not revealed to the public. Journalists rapacious for scandal-involving news are avoided definitely. Jules is furtively sent to a special clinic whose patients consist merely of people of clergy (abridged and adapted from pp. 75-76).

Now, the primary physician in charge of the treatment of this high religious dignitary is the head of sacerdotal (priestly) psycho-pathology chair in the University of Rome. Etiology, symptoms and prognosis are all analyzed carefully by further experts. A hallucinatory ecumenical case is mentioned. It could also be considered a divine phobia or a syndrome of Saint Benoit, whereby the patient attaches bigger significance to his own Saint than to the real "Boss", the Omnipotent Creator!

Such anomalies may well have their origins in the traumas (Figure 7) [10] experienced along the course of childhood catechism (early training in Christian religion). Sometimes even an extremely serious behavior called theo-psychosis or psychosis of divinity may emerge, whereby the person registers a regression back towards the paganist phase of mankind. Through thorough destruction of his faith, he cannot differentiate between the son and the Holy Spirit within the Trinity.

In a session of hypno-confession Jules revealed that God became Marxist. Saint Francis felt the need to usurp the power in heaven to 

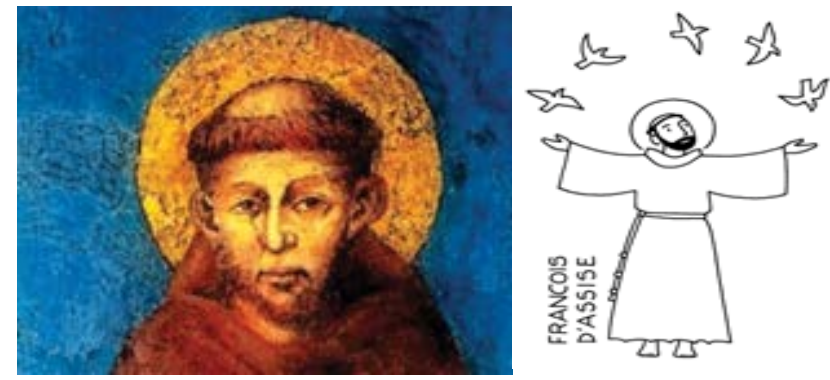

Figure 6: Representations of Saint Francis (internet).

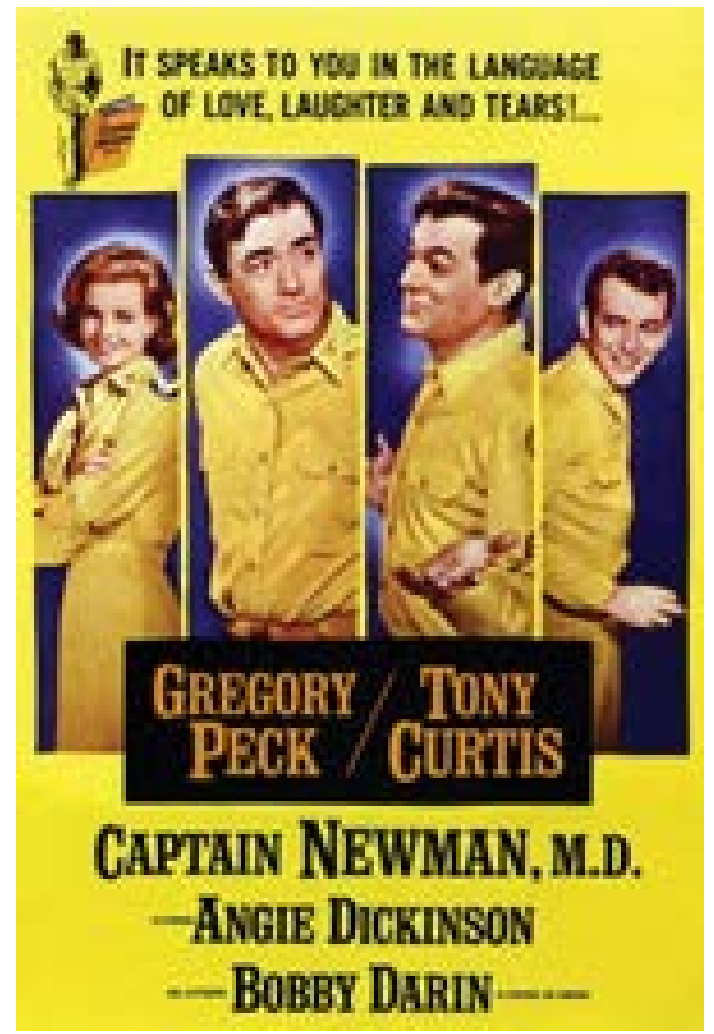

Figure 7: Poster of the mentioned psychological movie (internet).

achieve regulation. Fort his exalted purpose, he needed fresh troops consisting of authentic underprivileged souls!

Nun-Ernestine pays some visits to his elderly brother and the bishop-analyst explains that Jules is making progress. Jules murmurs prerogative phrases against Saint Francis like reactionary, butler of bourgeois, henchman of the capital. The abbey explains that he now takes his position under the flag of Seigneur, even though he believes that $\mathrm{He}$ is favoring communism. This is interpreted as making progress (abridged and adapted from p. 89-91.

\section{When the "Faith" Approves Commands or}

\section{Approves, any Act may Come Handy!}

Nat Turner (Figure 8) was a young, literate Black slave in Virginia. He used to read the Bible and preach sermons to other Blacks around. Eventually he would "receive" some "revelations" from the skies in the

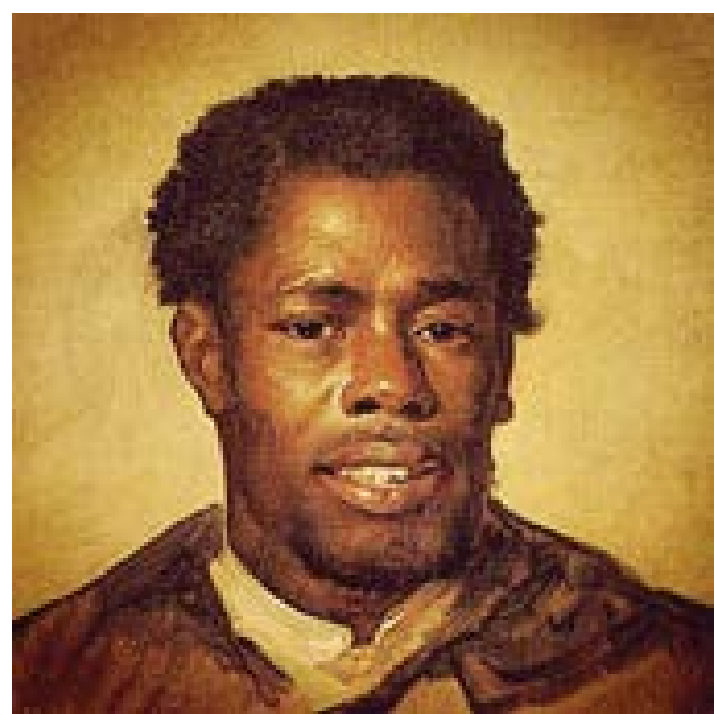

Figure 8: The infamous revolt-leader Nat Turner (internet).

line of commands like "thou shall slay the Whites". With a handful of followers, he would devastate the nearby farms and kill white people. This was a shock to the establishment, who gave him the capital punishment as a penalization of his deeds. Author William Styron turned his story into a historical novel, The Confessions of Nat Turner.

It is a known fact that certain new-religion or cult-movements, which entirely depart from mainstream religions prevalent in human societies since ages, may indeed sometimes urge their members towards unthinkable deadly acts.

In Japan, the guru of the cult of Aum Shinrikyo, Shoko Asahara, (following his unsuccessful try of spreading anthrax disease around), ordered a release of sarin gas in Tokyo subway, in March 1995. Ten people died and more than five thousand people got wounded. Other new so-called-religious sects may also display such absurd behavior patterns of giving harm to people in the society they live in.

In late 1970s, American cult leader Jim Jones obtained a base in Guyana in South America in order to remain away from American official posts, even though his disciples were recruited mostly from American people. When the sect organizations and activities became a matter of complaints due to informing knowledge and whistle-blowing; a congress member came for an inspection with his associates. Jones then realized that he couldn't conceal his activities any more. The sect decided for a mass-suicide, which caused great sensation all over the world. Dead bodies of hundreds of people, children included, were discovered prostrate.

All had taken cyanide salts. The cyanide anion $\mathrm{CN}$ - is very toxic. In the form of an entirely water-soluble salt like $\mathrm{KCN}$ or $\mathrm{NaCN}$ it is fatal. Former teacher Odell Rhodes survived. Camp physician (Larry) Schacht formulated the poisonous mixture with his nurses and asked Odell to go to fetch his stethoscope. He went but did not return. He watched the awful developments from his hidden location in the forest. It took five minutes for the cyanide salt to display its effects, enough time for the families to take the embraced position among themselves. As Odell narrates, only one woman tried to protest, but she got hushed up. How could she dare disobey the Father's order? The Father's own son was at a basketball match and was spared [9]. 
Another example of ritual-religious killing is to be found in the very demonstrative case of former. Thugees in India. Thuggees constituted a cult / order of males, who concealed themselves as ordinary people. In the winter season, they would go on roads, join travelers and at the proper moment strangle them and obtain their possessions. Their belief certified that the practice pleased their goddess Kâli. The religious aspects of their deeds imparted many rituals into the "play". After centuries of clandestine activity accompanied by and even collaboration by the local figures of power, the order was finally discovered and annihilated by the British authorities [10].

\section{A Jewish "version" (except for the violence element)}

We encounter an almost sickly version of being pious in the Jewish faith, in an American fiction work [11], except for the lack of crime element: In 1948, in a town named Woodenton, Eli is a JewishAmerican lawyer. The Jewish community is fairly integrated with the mainstream society, the Protestant majority. Two holocaust survivors, Hasidic and Tzuref, mean to open a yeshiva (a Jewish educational institution that focuses on the study of traditional religious texts) for orphans in a residential neighborhood.

Hasidic is walking about in his traditional black attire (his long black overcoat and beard and "braided" hair "spilling out" beneath the characteristic hat), collecting charities for the prospective school (Figure 9). Eli is hired by the community as a lawyer to discourage the two men from insisting on the residential area; so, Lawyer Eli and keeps visiting the two compatriots on a professional basis.

His personal embarrassment because of the "absurd" attire is overwhelming. So, he urges Tzuref to convince the "man in the suit" to take off his black one and put on a regular suit, instead. As in excuse to justify his friend's clothing, Tzuref claims his friend is too poor to buy a suit.

Finally, despite his wife's disapproval, Eli puts his own expensive green suit and some other spare ones in a box: Then he brings the box to the would-be-school. The community appreciates Eli's persuasion techniques when they witness his generosity. However, when the night falls, at his doorstep Eli finds the black suit and the hat of the orthodox [11] Jew, as if in payment for the given clothing. (At the moment, his pregnant wife Miriam is taken to the hospital for a delivery).

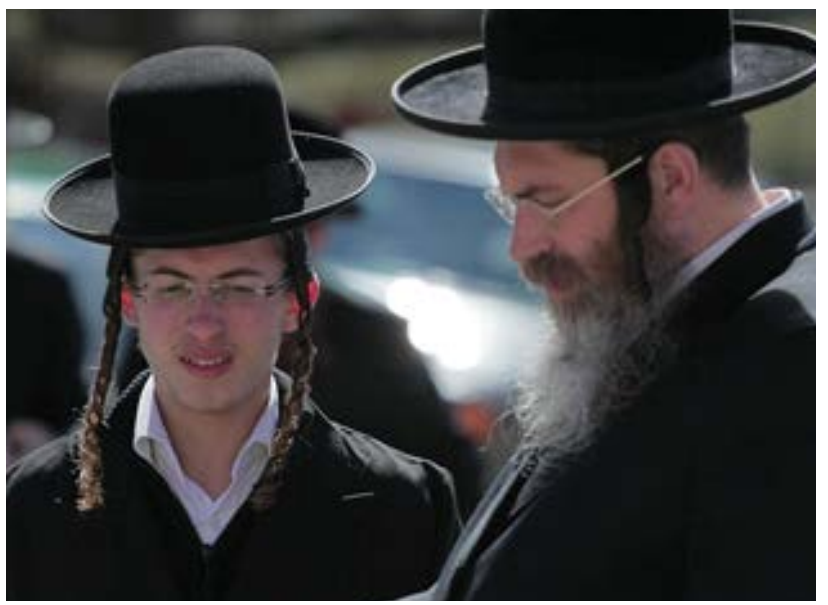

Figure 9: The above-mentioned attire (internet)
Eli gets curious and hesitantly puts on the discarded clothing. Then, all of a sudden, he starts walking openly through the town's streets and even returns to the hospital visit in that very same old attire. A few acquaintances of him arrive and contribute their aid to medical people in their efforts to capture Eli for a treatment for a "nervous breakdown".

In Samuel G Freedman's wording, the main theme of the author of the above-mentioned short story, Roth, is "the anxiety of the American Jew: The fear that every hard-won advancement, every material and social comfort -indeed, every sign of genuine acceptance in this overwhelmingly Christian nation - can be wiped away with shocking suddenness".

\section{Debate and Conclusion}

It may sometimes be difficult to differentiate between a mystical delirious case and a deeply devoted and pious behavior pattern. Many Muslims and Christians do believe in miracles or wonders or legends, which a positivist an all-rational mind may repudiate.

Certain historical sources mention about supernatural powers of ascetic men. In a biography book written from the point of view of Saladin, extraordinary talents are attributed to the Old Man of the mountain, the then-Master at the top of the hill Alamut. The order was known for his self-sacrifice-practicing adepts, the forefather of assassins. They were from the Ismailiyya branch of Shiite Islam. Their interpretation of religion was of an inner or esoteric sort (Batiniyah understanding).

I passed most of the night praying in my tent, before I fell asleep. A breeze startled me. On my bedhead I saw an apparition. A piece of bread baked the way the Batinis make it was put there along with a poisonous dagger piercing through a paper. I read the message: "What you possess will escape you in spite of everything and victory shall stay with us. You stand in our debt until you shall acquit it". The footprints on the lime dust were not even leading to the tent! Horrified, I gave in: I lifted the siege and we galloped towards the city of Hama $[12,13]$.

Regarding the city of Konya, where the tomb of the famous sufi Mevlana is, we run into the following dialogue (A local man is giving explanations to the visiting insurance agent):

- All right then. This is the legend: From the province of Khorasan, two dervishes came flying towards Anatolia.

- You mean they came by plane?

- What plane, Miss Greenwood? We are talking about almost a thousand years ago. The arrival of the Turks in Anatolia. These men of God were flying by themselves.

- "You mean like birds".

- "One of the dervishes, upon seeing the beautiful lands below, asked his travelling companion, 'What do you think, venerable old man, shall I perch here?' The other dervish looked down, and also finding the view to his liking, answered, 'Kon, ya!' meaning 'Yes, perch here!' And that's how they came to perch here, and the city's name became Konya" [14]. But the "border" of "lunacy" is easy to recognize by common people around. At a certain point, naïve belief is simply replaced by a sickly thought and there we start talking about delusions of a mystical character. Those patients who would go ahead and take life in accordance with their pathological mindsets are the ones who need to be enclosed and medically treated. Even then, the basic contemporary idea is far from being a vindictive penalization in the name of the society. Rather, it is solely prevention of probable wrong doing. 


\section{Notes}

1) Some of those labels may even overlap with one another. Some are completely of opposing nature.

There are many kinds of deliriums. Such a grouping is convenient: Inferiority (or micromania) type: Incapacity, culpability or autoaccusation, corruption, poverty, incurability, desperation, humility. Grandiose (or megalomania) type: Invention, filiation / nobility, (in the movie titled "Anastasia", starring Ingrid Bergman and Yul Brynner, a young girl claims to be the last Russian Tsar's daughter), richness, ambition, revendication (claim of some ownership). Negation type (dispelling motions directed towards imagined troubles) etc. Delusions are also seen in chronic alcoholism and syphilis [2].

2) Even though at first sight sexuality and mysticism seem incompatible; there are historical exceptional figures, Russian monk Rasputing being the best example. Leader of the religious order Branch Davidian, David Koresh who fought with security forces at the ranchheadquarters in Waco-Texas in April 1993, was also a hypersexual male. Another somewhat mystical and lecherous leader was former Endonesian president Ahmad Sukarno. In 1960 he got his sixth wife but his sexuality did dot pertain to legal wives alone. According to Willner [3], in Hinduist-Buddhist comprehension the sacred man is not an ordinary man in sexual matters. Instead, he is either one who vows a strict sexual "diet" (like Gandhi) or else one who is extremely active. Endonesia is a Muslim country where the ancient Hinduist-Buddhist roots and effects still linger [4].

3) In 1994 on the day of commemoration of the death of the founder of the Turkish Republic at the mausoleum of the historical figure, a man named Mahmut Kaçar lifted the sacred book of Islam, the Glorious Quran, in his right hand and addressed the ceremonial crowd:

\section{-Do not worship idols! Do worship Allah almighty!}

Security forces immediately captured him. The event caused a lot of turmoil. Strictly-laicized circles were horrified. Suleyman Demirel, the President of Turkey, alleviated the extreme social and political tension with the wording:

-Within a population of so many millions, the presence of a certain meczup should not be so surprising.

Thus, the word meczup became popularized, all of a sudden. In this manner, at the time, it came to the attention of young generations, who were unaware of old Ottom

an words.

4) I watched the movie years ago. Probably the movie stuck to my memory so well mainly due to the fact that my ex-wife resembles that actress, a lot.

5) Ord. Prof. Dr. Mazhar Osman Usman (1884-1951) is the forefather of modern Turkish Psychiatry. He moved the former Ottoman hospital in Scutari to a deserted military building in Bakirköy. For many years to come, the name of the district, the mental hospital and the founder Mazhar Osman were interchangeably used by masses.

6) In a certain episode of the work [7] the travelling kitchen offered to the main church by a fast-food company is driven by a high clergy in person, to a place where the homeless are assembled. Food will be distributed. The clergy is passionately talking about peace and love and is mispronouncing the latter word as luve, luuuuve. (In the original text, amûr, amûûuûr instead of amour). But a rival charity organization is there to reckon with! At the other extremity of the juncture is stationed another small truck: That which belongs to the disciples of the cult of Hare Krishna, those crazy persons who stroll in gowns barefooted and indifferent to the cold weather. Their heads are clean-shaved and an acre grain of butter is decorating their tattooed foreheads.

7) The champion of the new products is an Islamic prayer carpet convenient for all offices. Indeed, the following humorous sentence is from the mouth of a high manager:

-Cassock (soutane), confessional (an enclosed stall in a church in which a priest listen to people's confessions of their sins), crucifix, chalice (large cup or goblet, for keeping the sacred wine), censer! This proliferation of objects only confuses the minds! [7].

8) One morning, while Jules is kneeling for a prayer in the privacy of his room, a flaming light ray appears in escort of a sonorous supernatural voice. There is the Lord, talking to his humble creature!

-Jules, Jules, do you hear me?

-Lord, I drank a bit too much last night. Forgive me!

-That is only a trivial sin, you idiot!

Then the Lord goes ahead blames him for his collaboration with the establishment. How did he dare accept the donation of the small lorry from the fast-food chain? Jules senses that the Lord has been lately receiving the frequent visits of Karl Marx, who keeps indoctrinating (!) his own Creator along the line of his ideology! [7].

9) On another occasion, while Jules is resting in his unique armchair, it is Saint Francis who appears and starts talking!

-Brother François, how many times I implored for your aid before!

—Calm down Julot! If you could only guess the circus prevailing up there! The Boss is spending all his times with that abject Karl! It is by no means the Holy Trinity, up there anymore! Rather, it is the Politburo! Lord, I drank a bit too much last night. Forgive me!

Thanks to his spirituality the Saint keeps pacing the room through the furniture and other objects and keeps complaining about the awful development.

- True, I have seen evil times before. Churches became places of debauchery, while that half-wit Innocent III was gulping loukums on his throne. His hearth was worse than the home of Saladin! But, with respect to this new development it was only a minor catastrophe, even then! This horrible Karl (Marx) and his buddy Friedrich (Engels)!

Then Saint then starts shadow-boxing against Karl [7].

10) Indeed, some traumas may first go unnoticed, only to revive years later. For instance, Post-Traumatic Stress Disorder (PTSD) occurs only after a person is exposed to a traumatic event where their life or someone else's life is threatened. It is a tragedy of many war veterans. Captain Newman, M.D. was a superb 1963 American film starring Gregory Peck, Tony Curtis, Angie Dickinson.

The film is based on a 1961 novel by Leo Rosten. It was loosely based on the World War II experiences of Rosten's close friend Ralph Greenson. Greenson himself is well known for his work on posttraumatic stress disorder. He was a director of the Los Angeles Psychoanalytic Institute and was a practicing Freudian. Greenson is perhaps best known for his patients, who included Marilyn Monroe, Frank Sinatra, Tony Curtis and Vivien Leigh [8]. 
11) (Along the course of time) "Jews, not only in Europe but also in America, became divided into three groups: The orthodox, who resist all change in beliefs and ritual; the reform group, which rejects much of Jewish traditionalism and believes that Judaism should be regarded as a changing and developing religion; and the conservatives, who cannot accept the orthodoxy but who object to an extreme break with traditions, and who therefore seek a middle way" [12].

\section{References}

1. Çaya S (2012) Unpublished class notes for the undergraduate elective course: Behavioral sciences for engineers, Göztepe, Istanbul. Faculty of Engineering, Marmara University.

2. Adasal, Rasim (1977) Medical Psychology including the Normal and Abnormal Aspects (3rd edn.). Minnetoğlu Publications, Cağaloğlu, İstanbul.

3. Perretti M (1986) Willner, ann ruth, the spellbinders: Charismatic political leadership. Yale University Press, New Haven, London. pp: 144-145.

4. Daudet A (1866) "les étoiles" [the Stars], Lettres de mon moulin [Letters from my Windmill]. University of Toronto Library, Paris.

5. Çaya S (2014) Rasputin's profile and how charisma works in inducing others into guided actions of all sort. J Health Sci 2: 599-603.
6. İsmail E (1984) "Prophet Eshref" in Prophet Eshref and other short stories: A panorama of psychic adventures. Exposition Press, Smithtown, New York. pp: $51-55$.

7. Jonquet T (1998) The poor new man is here! Editions Méréal, Paris.

8. https://en.wikipedia.org/wiki/Knowledge

9. Çaya S (2015) Committing a crime with the employment of a toxic substance J Health Sci 3: 28-34.

10. Çaya S (2015) A historical murder-cult in former India. Frontiers of Legal Research 3: 26-36.

11. Roth $P$ (1959) Eli, the Fanatic. Goodbye, columbus and five other short stories. Houghton Mifflin Company, Boston, Massachusetts.

12. Hunt EF, Colander DC (1987) Social science: An introduction to the study of society ( $6^{\text {th }}$ edn.). MacMillan Publishing Company, New York. p. 454

13. Chauvel G (1992) Ich, Saladin: Das Schwert des Gerechten [I, Saladin: The Sword of the Righteous] (original title in French: Saladin, Rassembleur de I'Islam [Saladin, Gatherer of Muslims]). Bastei Lübbe, Berlin.

14. Ümit A (2011) The Dervish Gate (original Title in Turkish: Bâb-i Esrar). Everest Publications, Istanbul. 